University of Nebraska - Lincoln

DigitalCommons@University of Nebraska - Lincoln

Faculty Papers and Publications in Animal

Science

Animal Science Department

March 1995

\title{
Sperm Production in Boars After Nine Generations of Selection for Increased Weight of Testis
}

Thomas A. Rathje

University of Nebraska-Lincoln, trathje2@unl.edu

R. K. Johnson

University of Nebraska-Lincoln, rjohnson5@unl.edu

D. D. Lunstra

Roman L. Hruska U.S. Meat Animal Research Center, USDA-ARS, Clay Center, NE

Follow this and additional works at: https://digitalcommons.unl.edu/animalscifacpub

Part of the Animal Sciences Commons

Rathje, Thomas A.; Johnson, R. K.; and Lunstra, D. D., "Sperm Production in Boars After Nine Generations of Selection for Increased Weight of Testis" (1995). Faculty Papers and Publications in Animal Science. 93.

https://digitalcommons.unl.edu/animalscifacpub/93

This Article is brought to you for free and open access by the Animal Science Department at DigitalCommons@University of Nebraska - Lincoln. It has been accepted for inclusion in Faculty Papers and Publications in Animal Science by an authorized administrator of DigitalCommons@University of Nebraska - Lincoln. 


\title{
Sperm Production in Boars After Nine Generations of Selection for Increased Weight of Testis ${ }^{1,2}$
}

\author{
T. A. Rathje, R. K. Johnson, and D. D. Lunstra
}

Department of Animal Science, University of Nebraska, Lincoln 68583-0908 and Roman L. Hruska U.S. Meat Animal Research Center, ARS, USDA, Clay Center, NE 68933

\begin{abstract}
Body, testis, and epididymis weights were recorded and homogenization-resistant sperm nuclei were counted to determine daily sperm production and the number of sperm stored within the cauda epididymis (CAUDASP) in 145 boars of a control line (C) and 128 boars of a line selected for increased predicted weight of testis (TS) at $150 \mathrm{~d}$ of age. Random samples of boars were evaluated at five ages between 70 and $450 \mathrm{~d}$ in Generation 8 and 15 ages between 70 and $296 \mathrm{~d}$ in Generation 9. Data were analyzed using an animal model that included the fixed effect of line and the linear, quadratic, and cubic effects of age. Variance components were estimated using a DFREML algorithm. Boars of the TS and C line did not differ in body weight $(P>.05)$ in Generation 8. In Generation 9, boars of line TS were heavier between 118 and $198 \mathrm{~d}$ of age $(P<.001)$;
\end{abstract}

thereafter, body weights of the lines were similar $(P>$ $.05)$. The increase in organ weights for the testes and epididymides between 70 and $160 \mathrm{~d}$ of age were greater $(P<.01)$ for boars of line TS in each generation, and differences between the lines in testis weights established around puberty were maintained at $450 \mathrm{~d}$ of age. Daily sperm production and CAUDASP increased more rapidly at younger ages and plateaued at greater values $(P<.05)$ in boars of line TS. At ages less than $200 \mathrm{~d}$, boars of line TS produced more sperm per gram of parenchyma than control boars. Selection for greater predicted weight of paired testes resulted in increased body weight at younger ages, increased daily sperm cell production at all ages, and larger numbers of sperm stored in the cauda epididymis of young boars.

Key Words: Boar, Spermatozoa, Selection, Testes

J. Anim. Sci. 1995. 73:2177-2185

\section{Introduction}

Improvement of reproductive efficiency in swine has been traditionally accomplished by selection for female reproductive traits such as ovulation rate, litter size, litter weight, and age at puberty. Work by Land (1973) suggested that the same genes control gonadotropin secretion in both males and females. Therefore, selection for increased size of testes may be a method to improve reproductive traits of females.

Selection for size of testes could also affect reproductive capacity in males by increasing rates of sperm production, increasing the number of sperm cells stored in the cauda epididymis or by decreasing age at puberty. In the boar, testis size is positively

\footnotetext{
${ }^{1}$ Published as paper no. 10628, Journal Ser., Nebraska Agric. Res. Div., Univ. of Nebraska, Lincoln 68583-0908.

${ }^{2}$ Acknowledgments to Alan Krueger for technical expertise, Walt Stroup for assistance in optimizing the incomplete block design, and Keith Boldman for assistance in analysis of data.

Received February 24, 1994.

Accepted March 8, 1995.
}

correlated with sperm numbers found within the testis (Wilson et al., 1977). The objectives of this study were to estimate sperm production per gram of testicular parenchyma, daily sperm production, and the number of sperm cells stored in the cauda epididymis of boars between 70 and $450 \mathrm{~d}$ of age in a line of pigs selected for increased predicted weight of testis for nine generations and a randomly selected control line. The effects of this selection on testis, epididymis, and body weight and line $\times$ age interactions affecting these traits also were examined.

\section{Experimental Procedures}

\section{Data Description}

Selection for increased predicted weight of testis was initiated in a Large White-Landrace composite population in 1981. Length and width of paired testes of boars were measured with a caliper at 140 and 160 $\mathrm{d}$ of age and used to predict testis weight at $150 \mathrm{~d}$ of age. Mass selection was practiced. The realized 
heritability after 10 generations of selection was .35 and the response in predicted weight of testis was 18.7 $g$ per generation (Johnson et al., 1994).

The number of litters in the selected line (hereafter referred to as line TS) averaged 43 per generation, and the number of litters in the control line (designated line $\mathbf{C}$ ), which was selected randomly, averaged 42 per generation. In each line, 15 boars sired the litters in each generation.

Random samples of boars from both the eighth and ninth generations of selection were used in this experiment. The sample included five boars from each paternal half-sib family ( 75 boars per line) of both line $\mathrm{C}$ and line TS. A total of 124 boars was evaluated in Generation 8 and 149 boars in Generation 9. Loss of samples in Generation 8 occurred because boars were also sampled for histological evaluation and for some boars perfusion of one testis was not successful and the other testis was perfused so both testes were used for that experiment (Harder et al., 1995). One boar died during the experiment in Generation 9.

Boars were weaned at $28 \mathrm{~d}$ of age and placed in raised-deck nursery pens. At approximately $56 \mathrm{~d}$ of age, they were moved to a building that contained only boars and placed in groups of 9 to 10 pigs per pen. Boars were given ad libitum access to a diet containing $16 \% \mathrm{CP}$ until the average weight of the boars in each pen was approximately $60 \mathrm{~kg}$, after which the diet contained $14 \% \mathrm{CP}$. Boars were fed $2.3 \mathrm{~kg} / \mathrm{d}$ of the diet containing $14 \% \mathrm{CP}$ after reaching approximately $110 \mathrm{~kg}$ body weight. Diets and complete description of management of the boars are given by Johnson et al. (1994).

Boars from Generation 8, were randomly assigned within the paternal half-sib groups of each line to be castrated at $70,100,130,160$, or $450 \mathrm{~d}$ of age. Ages were selected to compare boars from the TS and C lines during the pubertal period and at maturity. A split-plot design was used with the subplot arranged as a randomized complete-block; sire groups were the blocking criteria. The main-plot treatment was genetic line and the subplot treatment was age at castration.

Boars from Generation 9 were randomly assigned within the paternal half-sib groups of each line to be castrated at one of 15 ages, beginning at $70 \mathrm{~d}$ of age and ending at $294 \mathrm{~d}$ of age, proceeding in 16-d intervals. Fifteen ages were used in Generation 9 to improve the accuracy of estimates of the regression coefficients for the age-curve describing testis, epididymis, and body growth and the development of sperm production traits (W. Stroup, personal communication). As in Generation 8, a split-plot was used. However, subplots were arranged as a partially balanced incomplete-block design again using sire groups as blocking criteria. Boars within each block were assigned randomly to castration ages in a manner allowing for maximum efficiency of comparisons among all line-age subclasses.
At the assigned age the boars were weighed (BDWT, kilograms) and castrated. Castrations were performed surgically while boars were under general anesthesia. Following a brief recovery period, boars were returned to their original pens. Both testes were removed, but only the left testis and epididymis were evaluated in Generation 8. The right side was used in Generation 9. One testis can be considered to be representative of both testes of the animal (Kennelly and Foote, 1964). It is possible that selection for testis weight could have affected the left and right testis differently; however, the assumption was made that both testes responded equally to selection for testis weight. Data reported herein should thus be doubled to be representative of the intact animal.

The testis and epididymis were immediately trimmed free of exterior tissue. The weight of the trimmed testis was obtained (TRIMWT, grams), the testis was decapsulated and the weight of the parenchymal tissue was recorded. Three samples of the parenchymal tissue, each weighing approximately $1 \mathrm{~g}$, were obtained from the proximal, mid, and distal regions of the testis and frozen. The trimmed epididymal weight was recorded (EPIDWT, grams) and the cauda portion was then separated from the corpus and caput segments and the cauda was frozen.

The procedure used to determine sperm production was based on counting homogenization-resistant spermatid nuclei as described by Amann and Almquist (1961). Spermatid nuclei resistant to homogenization were assumed to be from stages 6,7 , and 8 , of the cycle of the seminiferous epithelium. Thus, according to Swierstra (1968), the homogenization-resistant spermatid nuclei in the testis represent $4.37 \mathrm{~d}$ of sperm production in the boar.

For determination of sperm production, samples of parenchyma were thawed, weighed, and placed in 30.0 $\mathrm{mL}$ of ice-cold physiological saline solution $(.9 \%$ $\mathrm{NaCl}$ ) containing .1\% Triton X-100 (Scintillation grade, \#111020, Research Products International, Mount Prospect, IL). The individual samples were then homogenized with a Sorvall Omnimixer (three 30-sec homogenizations at maximum speed). One milliliter of the suspension was removed and mixed with $1 \mathrm{~mL}$ of Trypan blue stain $(.4 \%$ in phosphatebuffered saline, \#630-5250AG, Gibco/BRL, Grand Island, NY). Duplicate determinations of spermatid nuclei were made by totalling the number of nuclei in 5 of the 25 major squares of a hemacytometer. When duplicate counts differed by more than $20 \%$, samples were analyzed again to achieve uniformity. The counts, averaged across duplicates and locations, were multiplied by $3.0 \times 10^{6}$ to obtain an estimate of the average number of homogenization-resistant spermatid nuclei in the sample. The multiplication factor was derived from a 60 -fold dilution factor multiplied by the 50,000 hemacytometer factor. The total number of spermatids was divided by the average sample 
weight to estimate sperm production per gram (SPGM) of parenchymal tissue. Sperm per gram was multiplied by the total weight of the parenchyma of the testis to estimate total number of testicular sperm cells. Total number of testicular sperm cells was divided by 4.37 to estimate daily sperm production ( DSP).

The cauda epididymis was thawed and weighed. The entire cauda epididymis was then minced in a total of $200 \mathrm{~mL}$ of $.9 \%$ physiological saline solution containing . $1 \%$ Triton X-100 and homogenized for 2 min with a Polytron homogenizer at maximum speed. One milliliter of the homogenized solution was immediately removed and mixed with $1 \mathrm{~mL}$ of $.4 \%$ Trypan blue stain. One milliliter of the stained mixture was removed and diluted with $36.5 \mathrm{~mL}$ of $.9 \%$ physiological saline solution that resulted in a 15,000 -fold dilution. The number of sperm nuclei was determined with a hemacytometer as described previously. The duplicate counts were averaged and multiplied by $7.5 \times 10^{8}$ to obtain an estimate of total mature sperm per cauda epididymis (CAUDASP). The $7.5 \times$ $10^{8}$ multiplication factor resulted from a 15,000 -fold dilution multiplied by the 50,000 hemacytometer factor.

\section{Statistical Analysis}

The model fitted to the data was an animal model of the following form: $y_{i j k}^{*}=\alpha_{i}+\beta_{j}+\xi_{i j k}$, where $y_{i j k}^{*}$ is the standardized observation for a boar, $\alpha_{i}$ is the random effect of the ith animal, $\beta_{j}$ is the fixed effect of the jth line-age subclass, and $\epsilon_{\mathrm{ijk}}$ is the random residual error. The observations were standardized by weighting by the line-age subclass standard deviation to account for heterogeneity of variance among subclasses. No covariate for body weight was included for testis or epididymis weight or sperm production traits because adjustment to a constant age and body weight does not accurately represent the biology of the animal. The observation $\mathrm{y}^{*}$, animal effect $\alpha$, and residual effect $\epsilon$, were assumed to have variance equal to the following:

$$
\left[\begin{array}{c}
\mathrm{y}_{*} \\
\alpha \\
\epsilon
\end{array}\right]=\left[\begin{array}{ccc}
\mathrm{ZAZ} \sigma_{\mathrm{a}}^{2}+\mathrm{I} \sigma_{\mathrm{e}}^{2} & \mathrm{~A} \sigma_{\mathrm{a}}^{2} & \mathrm{I} \sigma_{\mathrm{e}}^{2} \\
\mathrm{~A} \sigma_{\mathrm{a}}^{2} & \mathrm{~A} \sigma_{\mathrm{a}}^{2} & 0 \\
\mathrm{I} \sigma_{\mathrm{e}}^{2} & 0 & \mathrm{I} \sigma_{\mathrm{e}}^{2}
\end{array}\right]
$$

Observations were correlated due to genetic relationships among the boars. Therefore, the assumed variance structure for the standardized observation was $\mathrm{V}=\mathrm{V}\left(\mathrm{y}^{*}\right)=\mathrm{ZAZ} \sigma_{\mathrm{a}}^{2}+\mathrm{I} \sigma_{\mathrm{e}}^{2}$, where $\mathrm{Z}$ is the coefficient matrix relating boars to observations, $A$ is the matrix of additive genetic relationships among animals, $\sigma_{\mathrm{a}}^{2}$ is the additive genetic variance of the standardized observation, I is the identity matrix, and $\sigma_{\mathrm{e}}^{2}$ is the environmental error of the standardized observation. These correlations among boars were accounted for to obtain best linear estimators of the fixed effects of age and line.

The homogeneity of mean squares for the TS and C lines within ages was tested using an approximate $F$. test, placing the larger mean square in the numerator. A chi-square test that accounted for unequal observations among subclasses was applied to test homogeneity of variances across ages (Gomez and Gomez, 1984). Heteroscedascity $(P<.05)$ existed among line-age subclasses for all traits examined (results not shown).

Due to heterogeneous variances, the nonsingular matrix for error variance of the original data, $R$, was $D$ $=\left[d_{j}\right]$, where $d_{j}$ represents different residual variances of each line-age subclass along the diagonal. Because heterogeneous variances existed, the ordinary least squares estimation equations, $b=\left(\mathrm{X}^{\prime} \mathrm{X}\right)-\mathrm{X}^{\prime} \mathrm{Y}$, were not valid because the residual matrix $R$ did not equal $I \sigma_{\mathrm{e}}^{2}$. Therefore, a transformation was used to convert the observations into a form in which $R$ had equal diagonal elements. The analysis was performed on observations that had been standardized through division by the estimate of the standard deviation of the respective subclasses to which the observations belonged (i.e., $y_{i j k}^{*}=y_{i j k} / \sigma_{j}$ ). One way to analyze data with unequal variances is to use weighted least squares procedures whereby the weighting matrix is the matrix of subclass variances. Analysis on standardized variables yields solutions equivalent to those obtained from a weighted least squares analysis after backtransformation. A log transformation was not used because the coefficient of variation was not equal across subclasses (data not shown).

Variance components were estimated by a derivative-free restricted maximum-likelihood algorithm (Smith and Graser, 1986; Graser et al., 1987) using a variation (Boldman and Van Vleck, 1991) of Karin Meyer's DFREML program (1988). It included the use of the full additive relationship matrix, from Generations 0 through 9 , for the population. It was necessary to assume the ratio of $\sigma_{\mathrm{e}}^{2}: \sigma_{\mathrm{a}}^{2}$ (i.e., heritability) did not change across line-age subclasses. Thus, we assumed the additive genetic variance for each trait remained proportional to the increasing residual variance yielding a constant value for the ratio of variances. Not making this assumption would require either estimation of the additive genetic variance at each age within lines, which would not be precise with the small number of animals at each age in this experiment, or the use of estimates of variance components from the literature, which do not exist at this time for the traits examined.

At convergence (i.e., change in the variance of the log-likelihood functions in the simplex between successive iterations of less than $1.0 \times 10^{-9}$ ), estimates of $\beta$ 
and predictions of $\alpha$ with BLUE and BLUP properties were obtained, assuming the estimated variance ratios were true values. Contrasts of estimable functions of the differences between line, linear, quadratic, and cubic effects of age, and interactions between line and the linear, quadratic, and cubic effects of age and respective standard errors were made with $k$ vectors. The $\mathrm{k}$ vectors were of full row rank and composed of coefficients appropriate to test the linear hypothesis described above.

Contrast solutions and standard errors for contrasts were estimated using the standardized variables and a backtransformation was conducted to obtain the true weighted least squares solutions and standard errors. Tests of significance were done using an approximate $t$-test by dividing the solution obtained for the contrast by the estimated standard error for the contrast using the standardized variables and comparing the value to a table of critical $t$-values to determine significance of the contrast.

\section{Results and Discussion}

The mean values and number of observations in each subclass are presented in Tables 1 and 2 for Generations 8 and 9 , respectively. The values given for TRIMWT, EPIDWT, and the sperm production traits represent only one testis of the animal.

Solutions to the linear contrasts are presented in Tables 3 and 4 for Generations 8 and 9, respectively. The weighted least squares solutions for line-age subclasses from the mixed-model analysis are plotted in Figures 1 through 4 . There were no line $\times$ age interactions $(P>.05)$ for body weight in Generation 8 (Figure 1a). However, in Generation 9, boars were weighed at more frequent intervals and the linear and cubic effects of age were different between lines $(P<$ .001 and $P<.01$, respectively). Boars from line TS were heavier during the pubertal period from 118 to $182 \mathrm{~d}$ and their growth slowed and plateaued at a younger age than $\mathrm{C}$ boars (Figure $2 \mathrm{a}$ ). Schinckel et al. (1984) found body weight from 98 to $140 \mathrm{~d}$ of age was higher in boars selected $(P<.05)$ for large testis size than in boars selected for small testis size. Selection for testis size adjusted for body weight in sheep resulted in decreased body weight, due largely to the negative pressure placed on body weight when testis size was adjusted for body weight (Haley et al., 1990). Hill et al. (1990) found selection for testis size resulted in mice that matured earlier and gained relatively more weight at younger ages than divergently selected mice. In our experiment, TS boars had more rapid increases in body weight before and around the age of puberty but did not differ from the $\mathrm{C}$ boars at more mature weights.

Initiation of limit-feeding at $110 \mathrm{~kg}$ could have suppressed weight differences between lines at the older ages. Limit feeding boars after they reach weights of $110 \mathrm{~kg}$ is standard industry practice. The effects of limit feeding on the results for testes traits, discussed subsequently, are not known. However, the genetic differences between lines were expressed in the environment of the feeding regimen described above.

Line interacted with the linear and quadratic effects of age $(P<.001$ and $P<.01$, respectively, Table 3 ) for weight of testis in Generation 8. Boars of line TS had testes that grew faster than those of line C. Differences between lines were established during puberty and maintained through $450 \mathrm{~d}$ of age (Figure 1b). In Generation 9, line interacted with the cubic effect of age $(P<.001$, Table 4$)$. The line $\times$ linear and line $\times$ quadratic effects were not significant. Boars from lines $\mathrm{TS}$ and $\mathrm{C}$ had testes that increased in weight at the same rate. However, the testicular growth curve of the TS boars was shifted to younger ages indicating an earlier age at puberty (Lunstra et

Table 1. Mean values for traits ${ }^{a}$ measured in Generation 8

\begin{tabular}{|c|c|c|c|c|c|c|c|}
\hline $\begin{array}{l}\text { Age, } \\
\mathrm{d}\end{array}$ & $\mathbf{n}$ & $\begin{array}{c}\text { BDWT, } \\
\text { kg }\end{array}$ & $\begin{array}{l}\text { TRIMWT, } \\
\mathbf{g} \\
\end{array}$ & $\begin{array}{c}\text { EPIDWT, } \\
\mathrm{g}\end{array}$ & $\begin{array}{c}\text { SPGM, } \\
10^{6}\end{array}$ & $\begin{array}{c}\text { DSP, } \\
10^{7}\end{array}$ & $\begin{array}{c}\text { CAUDASP } \\
10^{7} \\
\end{array}$ \\
\hline \multicolumn{8}{|c|}{ Control line } \\
\hline 70 & 15 & 22.2 & 13.8 & 4.2 & .9 & .2 & .8 \\
\hline 100 & 15 & 42.0 & 35.9 & 9.8 & .4 & .3 & 1.3 \\
\hline 130 & 15 & 67.8 & 86.9 & 21.0 & 7.0 & 15.7 & 95.8 \\
\hline 160 & 12 & 92.3 & 193.5 & 35.2 & 32.3 & 120.9 & $1,040.5$ \\
\hline 450 & 14 & 182.7 & 366.7 & 88.3 & 61.1 & 430.4 & $4,829.5$ \\
\hline \multicolumn{8}{|c|}{ - Testis weight line - } \\
\hline 70 & 13 & 22.8 & 18.8 & 4.9 & .3 & .1 & 1.2 \\
\hline 100 & 13 & 42.9 & 66.8 & 12.7 & 2.0 & 3.5 & 1.0 \\
\hline 130 & 13 & 69.7 & 159.7 & 28.1 & 20.4 & 73.0 & 294.6 \\
\hline 160 & 9 & 98.2 & 261.4 & 45.4 & 41.6 & 213.2 & $1,904.2$ \\
\hline 450 & 5 & 185.2 & 439.1 & 109.5 & 67.2 & 552.9 & $4,852.5$ \\
\hline
\end{tabular}

aBody weight (BDWT), testis and epididymis weight (TRIMWT, EPIDWT), sperm cell counts per gram of parenchymal tissue (SPGM), sperm cells produced per day (DSP), and sperm cell counts in the cauda segment of the epididymis (CAUDASP). 
Table 2. Mean values for traits ${ }^{\mathrm{a}}$ measured in Generation 9

\begin{tabular}{|c|c|c|c|c|c|c|c|}
\hline $\begin{array}{l}\text { Age, } \\
\text { d }\end{array}$ & $n$ & $\begin{array}{l}\text { BDWT, } \\
\text { kg }\end{array}$ & $\begin{array}{l}\text { TRIMWT, } \\
\text { g }\end{array}$ & $\begin{array}{c}\text { EPIDWT, } \\
\mathrm{g}\end{array}$ & $\begin{array}{c}\text { SPGM, } \\
10^{6}\end{array}$ & $\begin{array}{c}\text { DSP, } \\
10^{7}\end{array}$ & $\begin{array}{c}\text { CAUDASP, } \\
10^{7}\end{array}$ \\
\hline \multicolumn{8}{|c|}{ Control line } \\
\hline 70 & 5 & 19.5 & 11.6 & 3.9 & .5 & .1 & 0 \\
\hline 86 & 5 & 30.6 & 18.9 & 7.1 & .0 & .0 & 0 \\
\hline 102 & 5 & 40.9 & 44.8 & 9.8 & .5 & .7 & 0 \\
\hline 118 & 5 & 49.8 & 70.9 & 15.0 & 9.4 & 20.1 & 12 \\
\hline 134 & 5 & 63.2 & 113.2 & 22.8 & 20.3 & 49.6 & 89 \\
\hline 150 & 5 & 66.0 & 136.3 & 29.8 & 23.6 & 71.3 & 232 \\
\hline 166 & 5 & 81.8 & 191.9 & 39.2 & 59.6 & 247.1 & 532 \\
\hline 182 & 5 & 85.8 & 206.2 & 45.5 & 50.5 & 218.3 & 1,920 \\
\hline 198 & 5 & 98.4 & 234.6 & 53.2 & 50.8 & 247.5 & 2,160 \\
\hline 214 & 5 & 110.3 & 270.3 & 64.3 & 72.4 & 414.6 & 3,908 \\
\hline 230 & 5 & 112.1 & 245.1 & 64.2 & 69.1 & 367.2 & 2,970 \\
\hline 246 & 5 & 117.6 & 250.3 & 62.2 & 59.4 & 305.2 & 2,888 \\
\hline 262 & 5 & 128.4 & 243.8 & 65.6 & 51.9 & 257.8 & 3,353 \\
\hline 278 & 4 & 133.3 & 279.9 & 81.0 & 46.5 & 269.8 & 3,178 \\
\hline 294 & 5 & 135.4 & 222.4 & 66.1 & 50.2 & 251.5 & 3,023 \\
\hline \multicolumn{8}{|c|}{ - Testis weight line } \\
\hline 70 & 5 & 15.5 & 11.5 & 3.5 & 1.5 & .3 & 0 \\
\hline 86 & 5 & 28.4 & 40.1 & 8.1 & .7 & .8 & 0 \\
\hline 102 & 5 & 42.8 & 56.7 & 14.3 & .9 & 1.1 & 0 \\
\hline 118 & 5 & 55.6 & 137.8 & 26.0 & 66.7 & 201.0 & 304 \\
\hline 134 & 5 & 63.6 & 176.4 & 34.2 & 56.9 & 213.7 & 991 \\
\hline 156 & 5 & 78.0 & 237.9 & 42.9 & 62.1 & 300.1 & 1,554 \\
\hline 166 & 5 & 93.3 & 271.6 & 50.2 & 154.8 & 854.7 & 2,610 \\
\hline 182 & 5 & 103.1 & 308.6 & 67.1 & 76.4 & 488.6 & 2,285 \\
\hline 198 & 5 & 100.5 & 279.5 & 76.5 & 75.3 & 462.7 & 4,238 \\
\hline 214 & 5 & 117.7 & 262.7 & 66.2 & 58.6 & 326.4 & 3,728 \\
\hline 230 & 5 & 111.9 & 284.7 & 72.3 & 60.2 & 361.2 & 2,730 \\
\hline 246 & 5 & 117.3 & 296.2 & 81.5 & 71.3 & 443.1 & 4,058 \\
\hline 262 & 5 & 123.3 & 303.2 & 75.8 & 74.3 & 466.6 & 3,757 \\
\hline 278 & 5 & 128.4 & 264.3 & 81.4 & 42.6 & 243.2 & 4,680 \\
\hline 294 & 5 & 117.2 & 338.3 & 79.7 & 66.4 & 465.6 & 4,380 \\
\hline
\end{tabular}

aBody weight (BDWT), testis and epididymis weight (TRIMWT, EPIDWT), sperm cell counts per gram of parenchymal tissue (SPGM), sperm cells produced per day (DSP), and sperm cell counts in the cauda segment of the epididymis (CAUDASP).

Table 3. Solutions to linear contrasts, Generation 8

\begin{tabular}{|c|c|c|c|c|c|c|}
\hline \multirow[b]{2}{*}{ Effect } & \multicolumn{6}{|c|}{ Trait $^{b}$} \\
\hline & $\begin{array}{c}\text { BDWT, } \\
\text { kg }\end{array}$ & $\begin{array}{c}\text { TRIMWT, } \\
\mathbf{g}\end{array}$ & $\begin{array}{c}\text { EPIDWT, } \\
\text { g }\end{array}$ & $\begin{array}{c}\text { SPGM, } \\
10^{6} / \mathrm{g}\end{array}$ & $\begin{array}{l}\text { DSP, } \\
10^{7} / \mathrm{d}\end{array}$ & $\begin{array}{c}\text { CAUDASP, } \\
10^{7} \\
\end{array}$ \\
\hline $\mathrm{C}$ vs $\mathrm{TS}^{\mathrm{a}}$ & -3.0 & -49.8 & -8.7 & -6.2 & -5.6 & -21.26 \\
\hline \multicolumn{7}{|l|}{ Age } \\
\hline Linear & $122.5^{* * *}$ & $4.0^{* * *}$ & $75.2^{* * *}$ & $51.5 * * *$ & $41.6^{* * *}$ & $407.80^{* * *}$ \\
\hline Quadratic & $-28.5^{* * *}$ & .6 & $-10.4^{* * *}$ & $-15.5^{* *}$ & $-2.7 * * *$ & -7.53 \\
\hline Cubic & -5.8 & $-1.4^{* * *}$ & $-5.5 * * *$ & $-12.8^{* * *}$ & $-6.2 *$ & -63.09 \\
\hline \multicolumn{7}{|l|}{ Line $\times$ age } \\
\hline$(C$ vs TS $) \times$ Linear & -2.8 & $-4.1 * * *$ & $-16.5^{* * *}$ & $-3.4 * * *$ & $-9.6^{* * *}$ & 4.93 \\
\hline (C vs TS $) \times$ Quadratic & 3.6 & $1.2^{* * * *}$ & $3.8^{* *}$ & $9.0^{*}$ & $5.3^{* * *}$ & 60.30 \\
\hline$(\mathrm{C}$ vs $\mathrm{TS}) \times$ Cubic & 2.3 & -.4 & $.9^{*}$ & -1.6 & $2.4^{* * *}$ & 38.77 \\
\hline
\end{tabular}

${ }^{\mathrm{a}} \mathrm{C}=$ Control line, $\mathrm{TS}=$ Testis weight line.

${ }^{b}$ Body weight (BDWT), testis and epididymis weight (TRIMWT, EPIDWT), sperm cell counts per gram of parenchymal tissue (SPGM), sperm cells produced per day (DSP), and sperm cell counts in the cauda segment of the epididymis (CAUDASP).

$* P<.05$

$* * P<.01$.

$* * * P<.001$. 

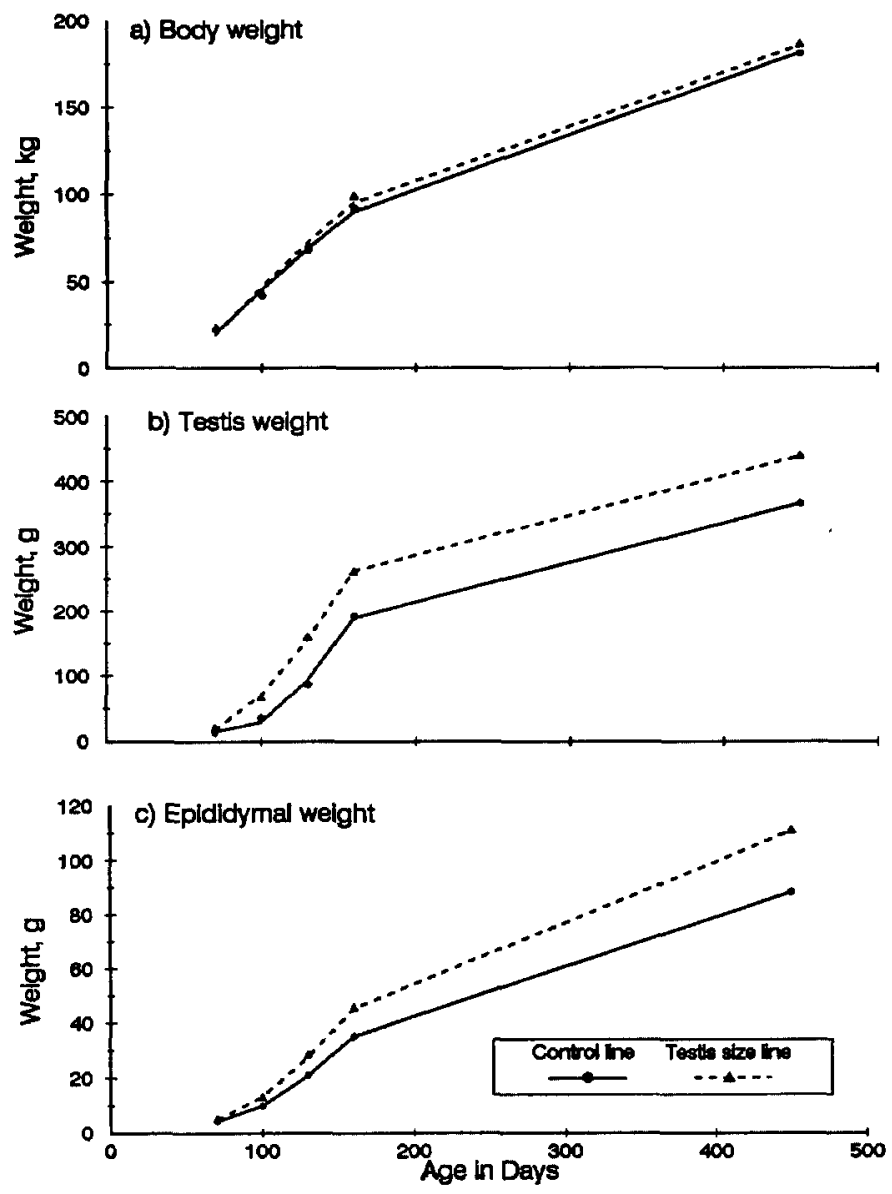

Figure 1. Body weight (a), left testis weight (b), and left epididymis weight (c) for boars of the control and testis size lines in Generation 8.
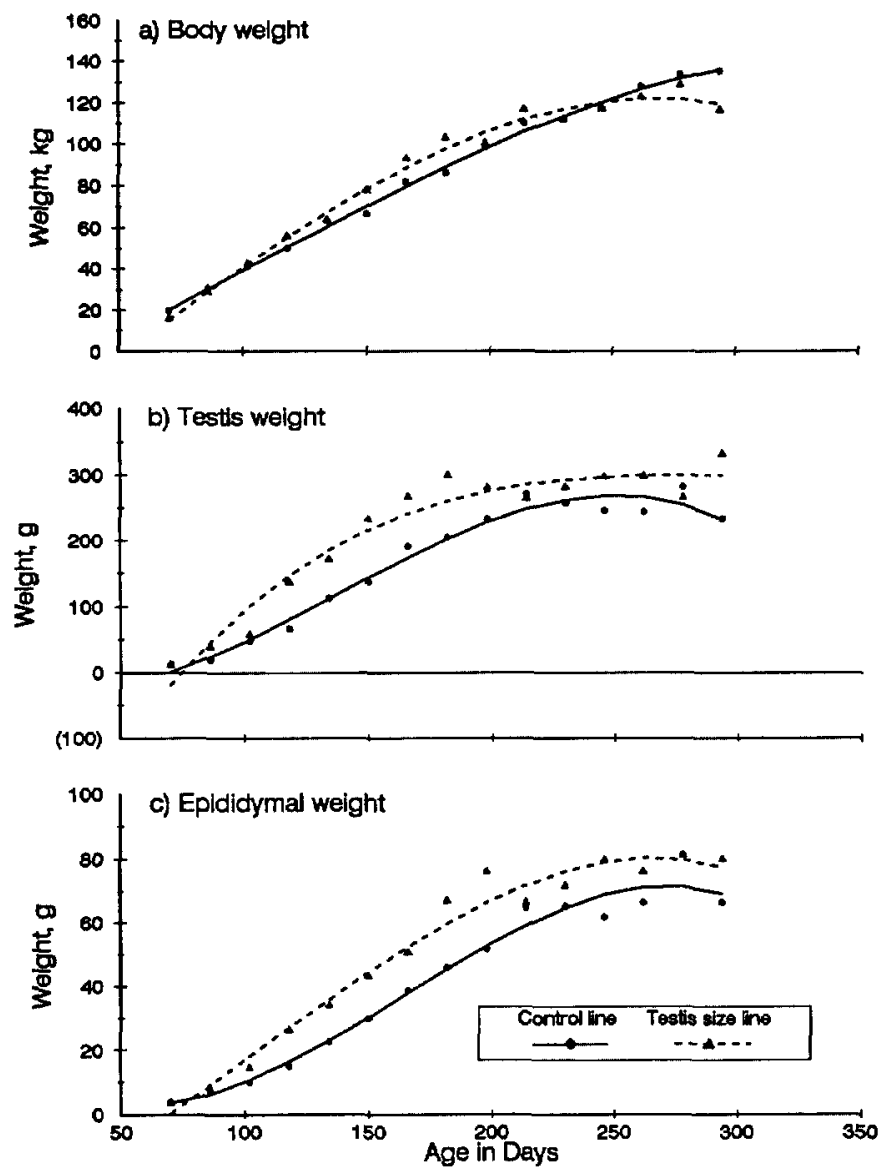

Figure 2. Body weight (a), right testis weight (b), and right epididymis weight (c) for boars of the control and testis size lines in Generation 9.

Table 4. Solutions to linear contrasts, Generation 9

\begin{tabular}{|c|c|c|c|c|c|c|}
\hline \multirow[b]{2}{*}{ Effect } & \multicolumn{6}{|c|}{ Trait $^{b}$} \\
\hline & $\begin{array}{c}\text { BDWT, } \\
\text { kg }\end{array}$ & $\begin{array}{l}\text { TRIMWT, } \\
\mathbf{g}\end{array}$ & $\begin{array}{l}\text { EPIDWT, } \\
\text { g }\end{array}$ & $\begin{array}{c}\text { SPGM, } \\
10^{6} / \mathrm{g}\end{array}$ & $\begin{array}{l}\text { DSP, } \\
10^{7} / \mathrm{d}\end{array}$ & $\begin{array}{c}\text { CAUDASP, } \\
10^{7}\end{array}$ \\
\hline $\mathrm{C}$ vs $\mathrm{TS}^{\mathrm{a}}$ & -1.3 & -45.1 & -9.8 & -.2 & -.1 & -1.0 \\
\hline \multicolumn{7}{|l|}{ Age } \\
\hline Linear & $2,286.2^{* * * *}$ & $5,712.0^{* * *}$ & $1,623.3^{* * *}$ & $11.7 * * *$ & $7.8^{* * *}$ & $95.0^{* * * *}$ \\
\hline Quadratic & $-5,176.7^{* * *}$ & $-26,123.2^{*}$ & $-3,770.7^{*}$ & $-123.0^{* *}$ & $-57.8^{* *}$ & -205.5 \\
\hline Cubic & $-803.0^{* * *}$ & $-2,336.9^{* *}$ & $-2,103.3^{* * *}$ & $5.8^{*}$ & -10.1 & $-259.5 * *$ \\
\hline \multicolumn{7}{|l|}{ Line $\times$ age } \\
\hline$(\mathrm{C}$ vs $\mathrm{TS}) \times$ Linear & $199.3 * * *$ & -275.8 & $-113.0^{* * *}$ & $3.1 * * *$ & -.6 & $-16.0^{* *}$ \\
\hline (C vs TS $) \times$ Quadratic & $4,964.0$ & $8,835.3$ & $2,998.8^{* * *}$ & $88.5^{*}$ & 51.1 & $332.8^{* * *}$ \\
\hline (C vs TS $) \times$ Cubic & $282.7 * *$ & $-15,904.6^{* * *}$ & $-1,261.1^{* * *}$ & -101.8 & $-49.7^{*}$ & -225.8 \\
\hline
\end{tabular}

${ }^{\mathrm{a}} \mathrm{C}=$ Control line, TS $=$ Testis weight line.

${ }^{b}$ Body weight (BDWT), testis and epididymis weight (TRIMWT, EPIDWT), sperm cell counts per gram of parenchymal tissue (SPGM), sperm cells produced per day (DSP), and sperm cell counts in the cauda segment of the epididymis (CAUDASP).

$* P<.05$.

$* * P<.01$.

$* * * P<.001$ 
al., 1986) in the TS line (Figure 2b). It is not clear from the results of Generation 9 if differences between the lines in testis weight were maintained at older ages as indicated by the results from Generation 8; however, the cubic interaction suggests a significant divergence between the lines at approximately $294 \mathrm{~d}$ of age.

In sheep, selection for increased testis size resulted in a more rapidly growing testis in immature animals but not a larger testis in mature animals (Haley et al., 1990). No similar experiments have been conducted in swine. Differences between boars of lines divergently selected for testis size need to be evaluated in mature animals as potential advantages in fertility for animals with large testis size would depend in part on line differences being maintained at older ages.

Patterns of epididymal growth were similar in Generations 8 and 9 . Line $\times$ age linear, quadratic, and cubic interactions $(P<.05)$ were found in each generation (Tables 3 and 4). Epididymides of TS boars increased in weight at a faster rate and reached a plateau at a greater weight than did those of $\mathrm{C}$ boars (Figures $1 \mathrm{c}$ and 2c). In Generation 8 advantages in epididymal weight were established during puberty and remained, or increased, to $450 \mathrm{~d}$ of age.

Line interacted with the linear and quadratic effects of age $(P<.05)$ for sperm produced per gram of testicular parenchyma in each generation. Boars of both lines began producing sperm cells at similar ages; however, in TS boars sperm produced per gram increased at a much faster rate (Figures $3 a$ and $4 a$ ). In Generation 8, differences in the efficiency of sperm production that were established during puberty were maintained to $450 \mathrm{~d}$ of age. This result is in conflict with the assumption that males of a species have similar efficiencies of sperm production (Amann and Schanbacher, 1983) when environmental influences are excluded. Clermont (1972) stated differences exist in the efficiency of sperm production amongst animals of the same species but of different strains. In Generation 8 of our experiment, selection for testis weight increased the efficiency of sperm production and the difference between lines was established during puberty and maintained at $450 \mathrm{~d}$ of age.

In Generation 9, the number of sperm produced per gram of parenchyma increased from 70 to $166 \mathrm{~d}$ of age in TS boars when it reached a maximum (Figure 4a). The extremely large value for sperm per gram of tissue at $166 \mathrm{~d}$ in the TS line was caused primarily by a single observation. Deleting the observation did not affect the conclusions. Therefore, the observation was not removed from the data set before final analysis. Subsequently, sperm production per gram of tissue in boars from line TS decreased to a value similar to that found in boars from Line C. In $\mathrm{C}$ boars, the rate of increase was more gradual. Several plausible explanations exist for such a phenomena. Lunstra et al.
(1986) stated that estradiol and testosterone output from boar Leydig cells in vitro increased during puberty to a peak at approximately $160 \mathrm{~d}$ of age. After $160 \mathrm{~d}$ of age, amounts of these hormones decreased to values characteristic of the adult animal. The increased amount of steroid in the animal before $160 \mathrm{~d}$ was also attributed to a rapid increase in the number of Leydig cells in the testis. Schinckel et al. (1984) found boars with large testes had greater, more variable values of $\mathrm{LH}$ concentration than boars with small testes, and these concentrations began to rise at younger ages and reached a greater maximum during puberty. Also, using 12- to 13-mo-old boars, Wolfe et al. (1989) found boars in the TS line had similar concentrations of circulating LH; however, boars from line TS secreted less LH in response to administration of exogenous LHRH than boars from line C. Therefore, hypothalamic control of hypophyseal secretion of $\mathrm{LH}$ may be different in boars from the TS and $\mathrm{C}$ lines.

Boars of the TS line may have been less sensitive to androgen feedback and(or) had larger populations of gonadotropin receptors in the testis during the pubescent period. Thus, it is possible that increasing levels of the gonadotropins in circulation, or increased sensitivity to gonadotropins, could have been driving the rate of spermatogenesis to a greater maximum in TS boars during the pubertal period. Perhaps, following the establishment of the negative feedback mechanism during the later pubescent period, sperm production per gram of tissue dropped to levels that were then maintained to $294 \mathrm{~d}$ of age in males of the TS line.

Because sperm production is a function of sperm produced per gram of testis tissue and testis weight, it closely followed the response of sperm produced per gram of tissue (Figures $3 \mathrm{~b}$ and $4 \mathrm{~b}$ ). In Generation 8 , the interactions of line with the linear, quadratic, and cubic effects of age were significant (Table 3). Daily sperm production in TS boars of Generation 8 increased at a faster rate during puberty and the advantage of TS boars established during puberty was maintained at $450 \mathrm{~d}$ of age.

In Generation 9, line interacted with the cubic effect of age on daily sperm production $(P<.05$, Table 4 ). The lack of interaction between line and linear and quadratic effects of age is probably because daily sperm production in TS and C boars increased at similar rates after the pubertal period had been initiated. The curve for development of daily sperm production was, however, shifted to younger ages, an indication that age at puberty was younger in TS boars (Figure 4b). The TS boars, in which sperm production increased at a rate similar to $\mathrm{C}$ boars, reached a greater maximum sperm production during puberty and then maintained it at a greater value than C boars from 198 to $294 \mathrm{~d}$ of age.

Daily sperm production is highly correlated with testicular weight. In this study, daily sperm production and trimmed testis weight had a correlation 

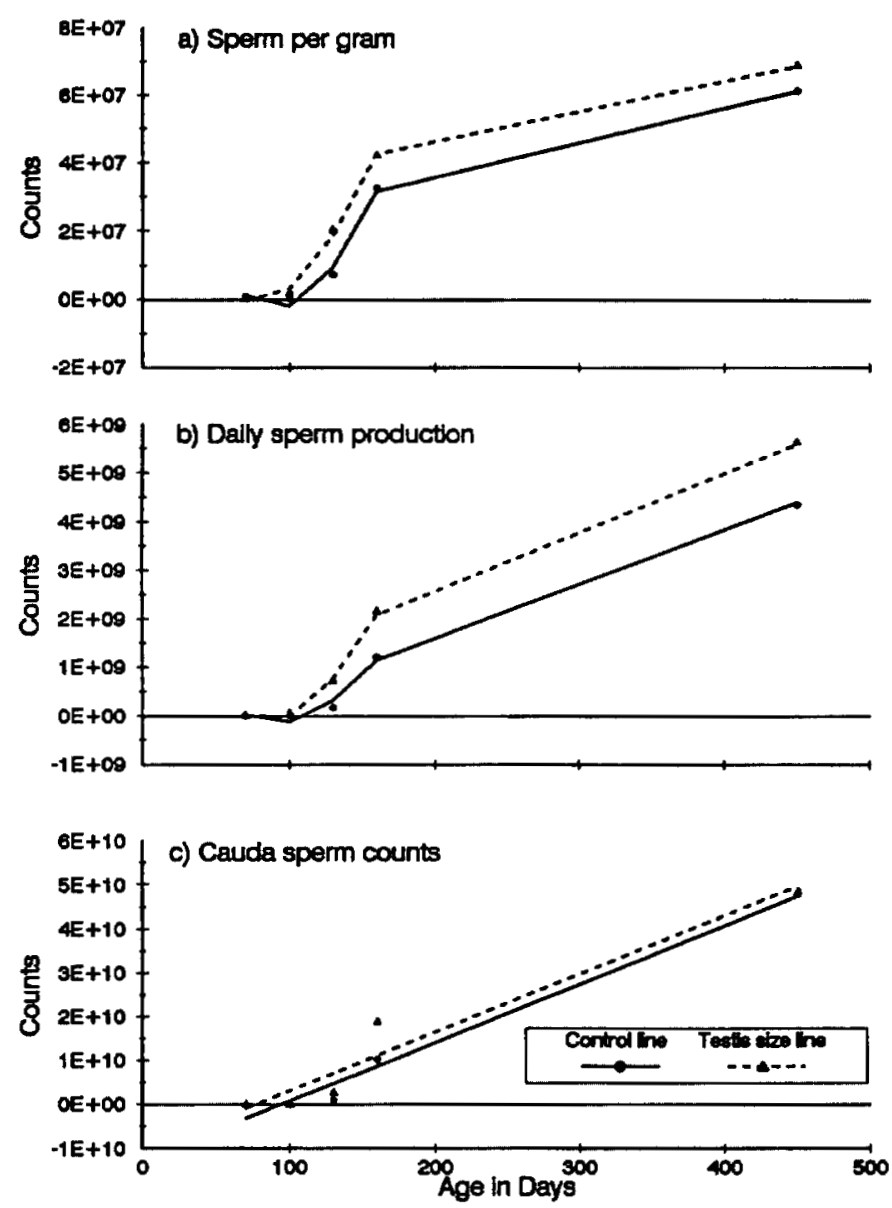

Figure 3. Sperm production per gram of parenchymal tissue (a), total sperm cells produced per day per testis (b), and total sperm cell counts per cauda epididymis (c) for boars of the control and testis size lines in Generation 8.

across all ages of $.90(P<.001)$ in Generation 8 and $.75(P<.001)$ in Generation 9. Cameron et al. $(1984)$ found a correlation of .90 between testis weight and sperm collected per day in rams. These results are in agreement with that of the bull (Amann and Almquist, 1962) and boar (Swierstra, 1971). In our study, differences in sperm production between the TS and C lines between 198 and $294 \mathrm{~d}$ of age in Generation 9 were largely due to differences in testis weight. However, results from Generation 8, and from Generation 9 at ages less than $198 \mathrm{~d}$, are an indication that differences also existed in efficiencies of sperm production (sperm production per gram of parenchyma).

In Generation 8, only the linear effect of age was significant (Table 3) for cauda sperm counts. No differences between lines were found at any of the ages sampled (Figure 3c).

In Generation 9 there was an interaction of line with linear and quadratic effects of age $(P<.001$, Table 4). Boars of the TS line were able to store larger numbers of sperm at younger ages than boars of the $C$ line, and their storage capacity increased at a faster rate and reached a plateau at a greater value (Figure 4c). A maximum in cauda sperm counts occurred at approximately $182 \mathrm{~d}$ of age in the TS boars, which was $16 \mathrm{~d}$ after their maximum daily sperm production. A maximum in number of caudal sperm cells occurred in $\mathrm{C}$ boars at approximately $214 \mathrm{~d}$ of age. After these maximums, number of cauda sperm cells decreased in both TS and C boars to a lesser value, but the plateau was greater in TS boars. The results for cauda cell counts followed results for daily sperm production by 12 to $16 \mathrm{~d}$, the approximate epididymal transit time for sperm cells in pigs. Boars from line TS in Generation 9 should have larger amounts of spermatozoa available for collection than boars from Line C; however, differences between lines in cauda sperm counts were not significant in Generation 8. Perhaps this occurred because boars were measured at several ages between puberty and maturity in Generation 9 , but no measurements were made between 160 and $450 \mathrm{~d}$ in Generation 8.

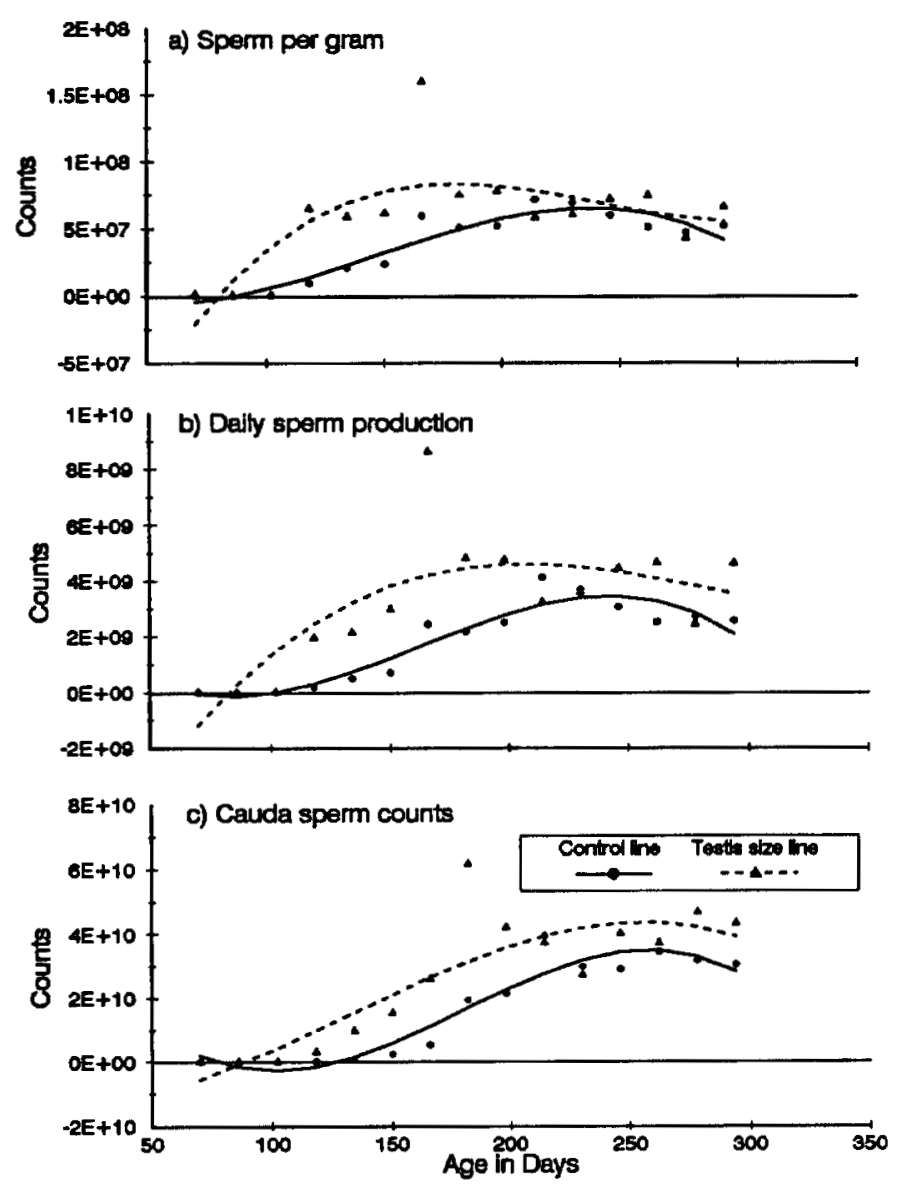

Figure 4. Sperm production per gram of parenchymal tissue (a), total sperm cells produced per day per testis (b), and total sperm cell counts per cauda epididymis (c) for boars of the control and testis size lines in Generation 9. 


\section{Implications}

Selection for increased weight of testis can be used to decrease the age at which boars begin producing sperm cells and to increase daily sperm production in young boars. There were larger numbers of spermatozoa in the epididymides of boars of the select line, but results of semen collection trials are needed to determine whether the ejaculum will contain more spermatozoa. Because weights of boars between 118 and $182 \mathrm{~d}$ of age was greater for select line boars, but weights of boars beyond $200 \mathrm{~d}$ of age did not differ for select and control boars, selection for testis weight and body weight might be a way to alter the growth curve of pigs without affecting body weights at older ages when boars are placed on a limited feeding regimen at $110-\mathrm{kg}$ body weight.

\section{Literature Cited}

Amann, R. P., and J. O. Almquist. 1961. Reproductive capacity of dairy bulls. I. Technique for direct measurement of gonadal and extra-gonadal sperm reserves. J. Dairy Sci. 44:1537.

Amann, R. P., and J. O. Almquist. 1962. Reproductive capacity of dairy bulls. VIII. Direct and indirect measurement of testicular sperm production. J. Dairy Sci. 45:774.

Amann, R. P., and B. D. Schanbacher. 1983. Physiology of male reproduction. J. Anim. Sci. 57(Suppl. 2):380.

Boldman, K. G., and L. D. Van Vleck. 1991. Derivative-free restricted maximum likelihood estimation in animal models with a sparse matrix solver. J. Dairy Sci. 74:4337.

Cameron, A.W.N., I. J. Fairnie, D. H. Curnow, E. J. Keogh, and D. R. Lindsay. 1984. The effect of frequency of semen collection and testicular size on the output of spermatozoa by rams. In: Cong. Proc. 10th Int. Congr. on Anim. Reproduction and A. I., June 10-14, 1984, Univ. of Ill. at Urbana-Champaign.

Clermont, Y. 1972. Kinetics of spermatogenesis in mammals: Seminiferous epithelium cycle and spermatogonial renewal. Physiol. Rev. 52:198.

Gomez, A. A., and K. A. Gomez. 1984. Test for Homogeneity of Variance. In: A. A. Gomez and K. A. Gomez (Ed.) Statistical Procedures for Agricultural Research (2nd Ed.). pp 469-471. John Wiley \& Sons, New York.
Graser, H.-U., S. P. Smith, and B. Tier. 1987. A derivative-free approach for estimating variance components in animal models by restricted maximum likelihood. J. Anim. Sci. 64:1362.

Haley, C. S., G. J. Lee, M. Ritchie, and R. B. Land. 1990. Direct responses in males and correlated responses for reproduction in females to selection for testicular size adjusted for body weight in young male lambs. J. Reprod. Fertil. 89:383.

Harder, R. R., D. D. Lunstra, and R. K. Johnson. 1995. Growth of testes and testicular morphology after eight generations of selection for increased predicted weight of testes at 150 days of age in boars. J. Anim. Sci. 73:2186.

Hill, W. G., P. J. Marks, J. C. Jenkins, and R. B. Land. 1990. Selection on testis size as an indicator of maturity in growing animals: I. Direct and correlated responses in growth. Genet. Sel. Evol. 22:231.

Johnson, R. K., G. R. Eckardt, T. A. Rathje, and D. K. Drudik. 1994. Ten generations of selection for predicted weight of testes in swine: Direct response and correlated response in body weight, backfat, age at puberty, and ovulation rate. J. Anim. Sci. 72: 1978.

Kennelly, J. J., and R. H. Foote. 1964. Sampling boar testes to study spermatogenesis quantitatively and to predict sperm production. J. Anim. Sci. 23:160.

Land, R. B. 1973. The expression of female sex limited characters in the male. Nature (Lond.) 241:208.

Lunstra, D. D., J. J. Ford, R. K. Christenson, and R. D. Allrich. 1986. Changes in Leydig cell ultrastructure and function during pubertal development in the boar. Biol. Reprod. 35:145.

Meyer, K. 1988. DFREML. Programs to estimate variance components for individual animal models by restricted maximum likelihood. User Notes. Univ. of Edinburgh, Scotland.

Schinckel, A. P., R. K. Johnson, and R. J. Kittok. 1984. Testicular development and endocrine characteristics of boars selected for either high or low testis size. J. Anim. Sci. 58:675.

Smith, S. P., and H.-U. Graser. 1986. Estimating variance components in a class of mixed models by restricted maximum likelihood. J. Dairy Sci. 69:1165.

Swierstra, E. E. 1968. Cytology and duration of the cycle of the seminiferous epithelium of the boar; Duration of spermatozoan transit through the epididymis. Anat. Rec. 161:171.

Swierstra, E. E. 1971. Sperm production of boars as measured from epididymal sperm reserves and quantitative testicular histology. J. Reprod. Fertil. 27:91.

Wilson, E. R., R. K. Johnson, and R. P. Wettemann. 1977. Reproductive and testicular characteristics of purebred and crossbred boars. J. Anim. Sci. 44:939.

Wolfe, P. L., M. W. Wolfe, T. T. Stumpf, R. J. Kittok, R. K. Johnson, and J. E. Kinder. 1989. Response to luteinizing hormone releasing hormone in postpubertal boars with large testes. Domest. Anim. Endocrinol. 6(3):211. 